\title{
Migration and swimming depth of Atlantic salmon kelts Salmo salar in coastal zone and marine habitats
}

\author{
Richard D. Hedger ${ }^{1,6, *}$, Daniel Hatin ${ }^{2}$, Julian J. Dodson ${ }^{1}$, François Martin ${ }^{1}$, \\ Denis Fournier ${ }^{3}$, François Caron ${ }^{4}$, Fred G. Whoriskey ${ }^{5}$ \\ ${ }^{1}$ Département de Biologie, Université Laval, Québec, Québec G1K 7P4, Canada \\ ${ }^{2}$ Direction de l'expertise Faune-Forêts-Territoires de l'Estrie-Montréal-Montérégie et de Laval-Lanaudière-Laurentides, \\ Ministère des Ressources naturelles et de la Faune du Québec, 201 Place Charles Le Moyne, Longueuil, Québec J4K 2T5, \\ Canada \\ ${ }^{3}$ Service de la faune aquatique, Direction de l'expertise sur la faune et ses habitats, Ministère des Ressources naturelles et de \\ la Faune du Québec, 880 Chemin Sainte-Foy, Québec, Québec G1S 4X4, Canada \\ ${ }^{4}$ Direction de l'aménagement de la faune du Saguenay-Lac-Saint-Jean, Ministère des Ressources naturelles et de la Faune du \\ Québec, 3950 Boul. Harvey, Jonquière, Québec G7X 8L6, Canada \\ ${ }^{5}$ Atlantic Salmon Federation, PO Box 5200, St. Andrews, New Brunswick E5B 3S8, Canada \\ ${ }^{6}$ Present address: Norwegian Institute for Nature Research, Tungasletta 2, Trondheim 7485, Norway
}

\begin{abstract}
Factors influencing the migration and swimming depth of Atlantic salmon kelts Salmo salar L. within the York Estuary and Gaspé Bay (Québec, Canada), and in the Gulf of St. Lawrence between Gaspé Bay and the Strait of Belle Isle (Newfoundland, Canada) were studied using acoustic telemetry. In 2006 and 2007, a total of 49 kelts were tagged with acoustic transmitters equipped with depth sensors, released in the river delta leading into the estuary, and tracked using a fixed receiver array within the estuary and the bay. A large variation in migratory behavior existed, with some kelts making a direct, strongly oriented traverse across the estuary and bay, and others showing multiple changes in orientation. There was long-term residence (typically several weeks) in the river delta and rapid migration once kelts reached the estuary and bay resulting from seaward swimming, with a net seaward movement even on a flood tide. Diving was more frequent during daytime. It was hypothesized that diving may have been related to feeding and/or the identification of more temporally consistent sub-surface salinity gradients or current flow directions. The patterns of migration within the coastal zone were similar to those identified for smolts, implying a universal pattern of coastal zone migratory behavior in both smolts and kelts. Migration speed within the marine habitat was dependent on date of departure from Gaspé Bay, which in turn was dependent on the length of time kelts had remained in the delta. It was hypothesized that extended feeding within the delta allowed kelts to improve their physical condition, enabling them to migrate more rapidly in the marine habitat.
\end{abstract}

KEY WORDS: Telemetry · Migration · Diving $\cdot$ Atlantic salmon kelts

\section{INTRODUCTION}

Postspawning survival rates are quite variable among salmonid fishes, with Salvelinis and Salmo species exhibiting relatively high survival, due to their ability to restore lost somatic energy reserves and to escape exploitation (Niemelä et al. 2000). Atlantic salmon Salmo salar kelts, defined as salmon that spawned the previous autumn (Allan \& Ritter 1977), return to the marine environment usually during the spring following the fall spawning period (Bardonnet \& Baglinière 2000, Niemelä et al. 2000). Surviving kelts 
may make annual returns to rivers for repeat spawning, and given that the fecundity of repeat spawners tends to be greater than that of first-time spawners, repeat spawning may mitigate individual years of reproductive failure and contribute towards genetic diversity (Ducharme 1969, Niemelä et al. 2000). It has thus been suggested that stock management measures should be implemented to protect kelts during their seaward migration (Niemelä et al. 2000).

Very little is known about the coastal zone and marine ecology of salmon kelts (Reddin et al. 2004) and the few published accounts available are not consistent. Some authors have identified kelt migration as being nocturnal (Bendall et al. 2005 for sea trout Salmo trutta kelts), while Östergren \& Rivinoja (2008) found that sea trout migration tended to occur during daytime. In the case of Atlantic salmon kelts, Scruton et al. (2007) reported nocturnal migration, whereas no diurnal patterns were observed by Hubley et al. (2008). Bendall et al. (2005) found that sea trout migration tends to occur on the ebb tide. These authors also showed the dependency of migration speed on river discharge and temperature, but were unable to separate the 2 variables because of their co-dependence. Several studies have shown the importance of diving in adult salmon (reviewed by Reddin et al. 2004). Most have shown that salmon mainly occupy surface or near-surface waters, with periodic descents to deeper waters: Karlsson et al. (1996) for Baltic salmon; Westerberg (1984), Doving et al. (1985), Reddin et al. (2004), Hubley et al. (2008), Halttunen et al. (2009) for Atlantic salmon. For Pacific salmon, diving has been related to diel period, with increased diving during daytime (Walker et al. 2001), but there has been some inconsistency among the results of different authors. Periodic excursions to deeper waters have been related to feeding, thermoregulation, determining orientation for migration, and/or olfactory exploration (Westerberg 1984, Wada \& Ueno 1999). It has been hypothesized that diving during daytime may also be related to avoidance of avian predators such as osprey Pandion haliaetus and bald eagle Haliaeetus leucocephalus (Reddin et al. 2004, Hubley et al. 2008).

Acoustic telemetry has been an effective method for describing fish migration patterns and inferring mechanisms of migration. The procedure involves tagging individuals with ultrasonic transmitters (Voegeli et al. 1998) and monitoring their movement using acoustic receivers, either moored in fixed linear arrays (e.g. Finstad et al. 2005, Lacroix et al. 2005) or through mobile tracking (e.g. Thorstad et al. 2004, Økland et al. 2006). Given that fish detections by widely-spaced fixed receiver arrays or periodic mobile tracking are generally sparse, these methods provide, at best, comprehensive descriptions of migratory pathways and be- havior. If, however, multiple receivers are moored in close enough proximity, fish positions may be interpolated to provide relatively uninterrupted records of individual behavior over large areas and extended periods of time (Hedger et al. 2008b). Atlantic salmon smolts have been particularly well studied using various telemetry techniques (Martin et al. 2009, and references therein) but a similar effort has not been invested in the kelt life-stage, with certain notable exceptions such as Hubley et al. (2008) and Halttunen et al. (2009). In both of these studies, receivers were separated by relatively large distances, limiting the ability to determine fine-scale movements, and were only placed within river and coastal zone environments, thereby forgoing their applicability in determining marine movements. The potential for improved telemetry studies will increase with developments in the infrastructure of telemetry configurations associated with the Ocean Tracking Network (Holden 2006).

In this paper, acoustic telemetry was used to monitor the migration of wild Atlantic salmon kelts within a fine-scale fixed receiver array in an estuary-coastal embayment system. The influence of physical habitat characteristics on movement patterns and swimming depth was examined. The main objectives were (1) to quantify kelt migration patterns within the estuarycoastal embayment system at a finer spatial and temporal scale than has been previously achieved, (2) to determine the factors controlling the seaward migration and swimming depth, (3) to determine the migratory (active swimming vs. passive drifting) and orientation mechanisms, and (4) to compare the migration patterns with those of previous studies of smolts in the same study area to determine if behavioral consistency exists across life-stages.

The extent of kelt migrations at sea is not well known. In the maritime provinces of Canada, there appear to be 2 migratory tactics: consecutive-year spawning of fish that reside in coastal waters for a short period of time, and alternate-year spawning of fish that may migrate much further to the Labrador Sea between Canada and Greenland (Ritter 1989). In Québec, $~ 80 \%$ of repeat spawners are alternate-year spawners that migrate out of the Gulf of St. Lawrence, possibly to avoid cold winter temperatures in the Gulf, and the remaining $\sim 20 \%$ are composed of fish that stay in the gulf to spawn the same year (Ministère des Ressources Naturelles et de la Faune du Québec, unpubl. data). Atlantic salmon kelts originating in rivers of the north shore of the Gulf of St. Lawrence have been observed at river mouths in the vicinity of the Strait of Belle Isle (Colombani et al. 1998). This suggests that salmon kelts from some Québec rivers may migrate to the Labrador Sea, as do Atlantic 
(a)

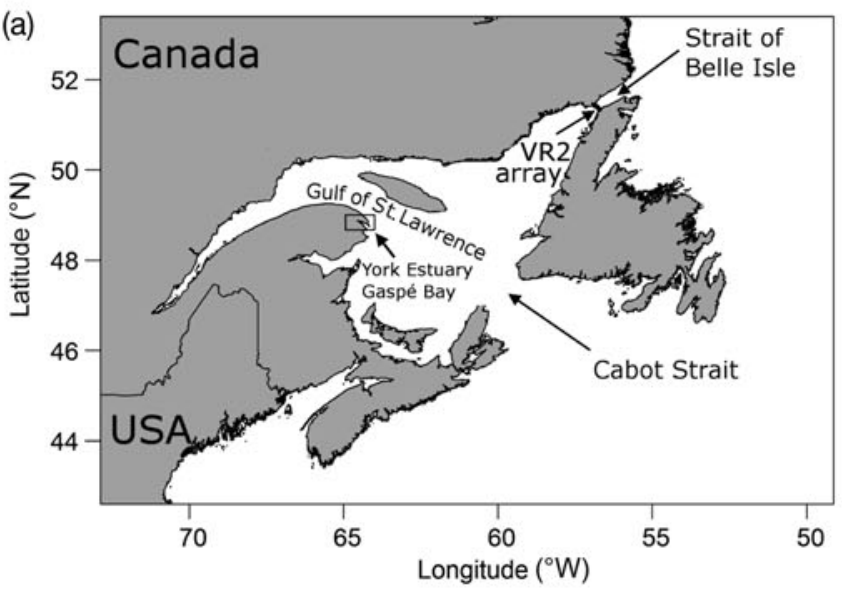

(b)

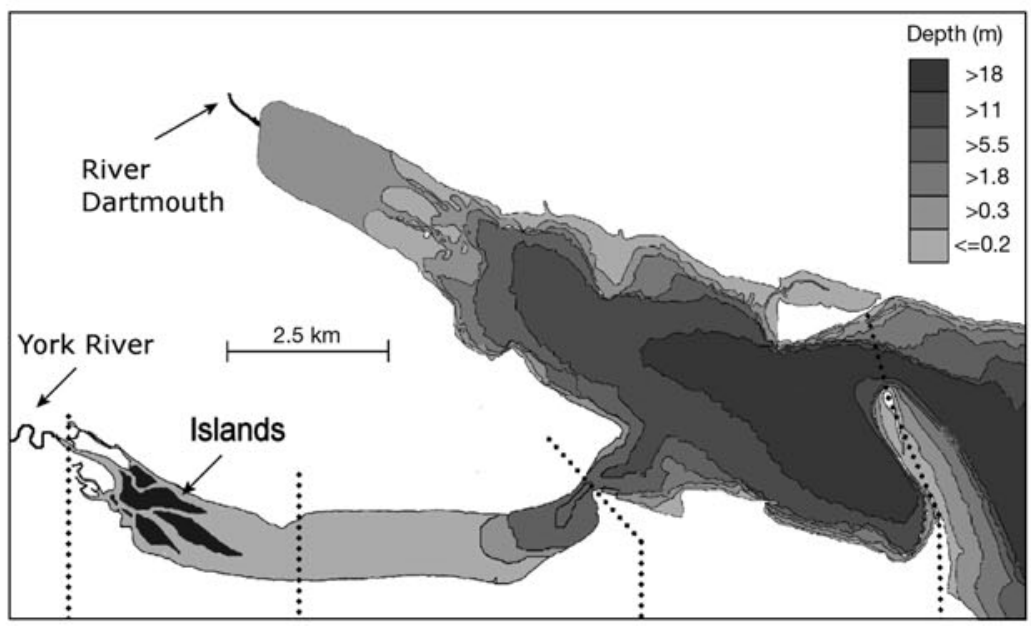

River

Delta

Estuary

Inner Bay

Outer

(c)

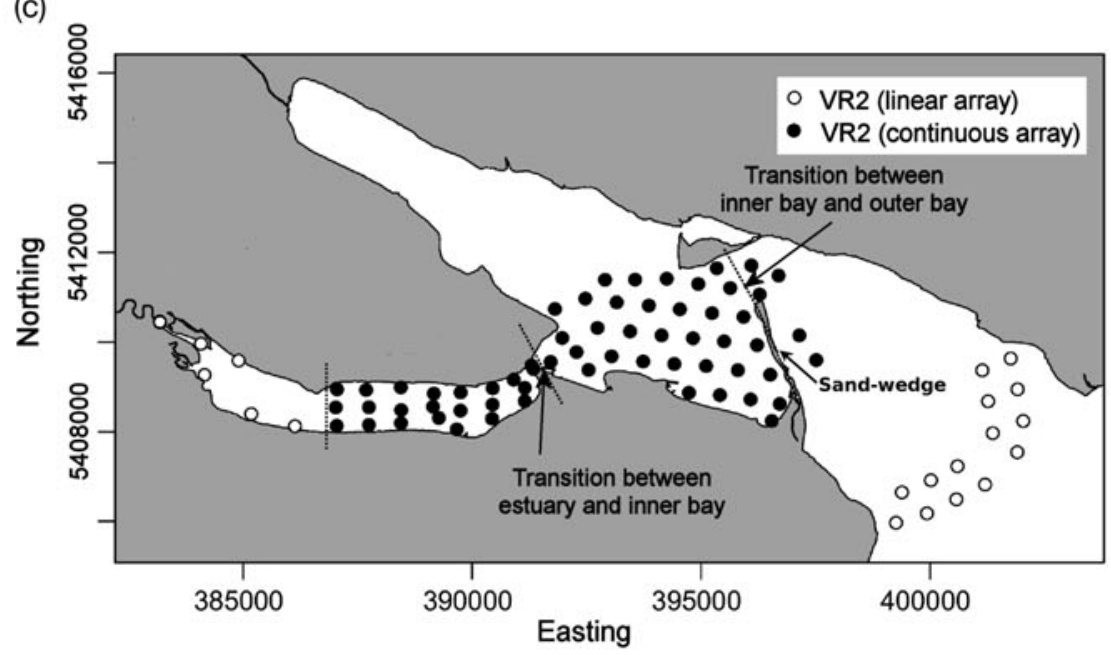

Fig. 1. The study area showing (a) Gaspé Bay and the Strait of Belle Isle; (b) bathymetry of the coupled estuary-coastal embayment system, York Estuary and Gaspé Bay; and (c) the receiver array in 2006 (in Universal Transverse Mercator coordinates). The Labrador Sea is north-east of the Strait of Belle Isle

\section{MATERIALS AND METHODS}

Study area. The principal study area was a coupled estuary-coastal embayment system, York Estuary and Gaspé Bay, located on the north eastern coast of Gaspésie, Québec, Canada $\left(48.85^{\circ} \mathrm{N}\right.$, $64.45^{\circ} \mathrm{W}$ ) (Fig. 1a). For the purpose of this study, the system is divided into 4 regions: (1) delta (at the transition between the estuary and the York River that flows into it); (2) estuary; (3) inner bay; and (4) outer bay (Fig. 1b). The delta stretches for several $\mathrm{km}$ from the York River, and its flow and water quality characteristics are dominated by the discharge from the river: tidal effects are absent, water is fresh, and temperature varies on a diel basis. The estuary is shallow, with a mean depth of $\sim 3 \mathrm{~m}$, but depth increases to $>10 \mathrm{~m}$ in a narrow trench separating the estuary from Gaspé Bay. Salinity and temperature within the estuary are controlled by the balance between freshwater input from the river into the delta (the discharge of which varies greatly on an annual basis, predominantly due to floods in May from snowmelt) and the intrusion of water of greater salinity into the estuary from Gaspé Bay. The coastal embayment, Gaspé Bay, is composed of 2 distinct regions: a partially enclosed inner bay and an open outer bay. The inner bay is wide $(>4 \mathrm{~km}$ ) and shallow (a maximum depth of $25 \mathrm{~m}$ ) relative to its length $(\sim 10 \mathrm{~km})$. It is separated from the outer bay by a sand-wedge, which is submersed at high tide. There is a relatively deep channel in the north $(\sim 1 \mathrm{~km}$ in 
width and $20 \mathrm{~m}$ in depth) where the bulk of the interchange of water between the inner and outer bays occurs. Gaspé Bay is typically vertically stratified in summer, with a surface layer of warm low-salinity water of riverine origin overlying a layer of colder saline water of maritime origin (Carrière 1973, Koutitonsky et al. 2001), although stratification may disappear for brief periods on a non-periodic basis. A horizontal salinity gradient generally exists across the bay, but this salinity gradient is not temporally persistent, and there may be localized (both spatially and temporally) reversals in the local salinity gradient due to the interaction between inputs of freshwater and surface eddying (Hedger et al. 2008b).

York River is a major salmon river, supporting an annual run of $\sim 1750$ adult salmon. Spawning grounds are located between 10 and $80 \mathrm{~km}$ upstream. Approximately $27 \%$ of spawners are grilse (having spent 1 yr at sea), the rest are multi sea-winter salmon. Of these latter fish, $55 \%$ have spent $2 \mathrm{yr}$ at sea, $30 \%$ have spent $3 \mathrm{yr}$ at sea and $15 \%$ are repeat spawners (Ministère des Ressources Naturelles et de la Faune du Québec, unpubl. data). Downstream migration of kelts occurs in April and May, with kelts migrating through the estuary and coastal embayment into the Gulf of St. Lawrence.
Kelt capture, tagging and tracking. Migration patterns of Atlantic salmon kelts were studied using 49 kelts (24 in 2006; 25 in 2007) tagged with coded ultrasonic transmitters equipped with pressure sensors to record the swimming depth (Vemco Ltd, V9P-2L model, $47 \times 9 \mathrm{~mm}, 6.4 \mathrm{~g}$ in air, random burst rate 20 to $50 \mathrm{~s}$, frequency $69 \mathrm{kHz}$, life time $150 \mathrm{~d}$ ). Kelts were captured by sport angling (baited hook) near to the intersection of the York River and the river's delta from 26 April to 1 May 2006 and 2 to 4 May 2007. Mean fork length and weight of the tagged kelts were $70 \mathrm{~cm}$ (range: 49.5 to 109.5 ) and $2.5 \mathrm{~kg}$ (range: 0.8 to 8.5 ) in 2006 and $80.4 \mathrm{~cm}$ (range: 54.1 to 106) and $4.0 \mathrm{~kg}$ (range: 0.8 to 9.0 ) in 2007 (Table 1). Kelts shorter than $63 \mathrm{~cm}$ were probably grilse $(\mathrm{n}=18)$, and kelts longer than $63 \mathrm{~cm}$ were probably 2 or 3 sea-winter fish $(\mathrm{n}=31$ ) (Ministère des Ressources Naturelles et de la Faune du Québec, unpubl. data).

A standard surgical procedure was used for transmitter implantation, which included anaesthesia (5 to $10 \mathrm{~min}, 45 \mathrm{mg} \mathrm{l}^{-1}$ clove oil solution), disinfection ( $0.05 \%$ chlorexidin solution), body cavity incision ( 2 to $3 \mathrm{~cm}$ long anterior from the pelvic girdle), suturing (3 to 4 simple interrupted sutures, Prolene $8685 \mathrm{H}, 2$ to $0 \mathrm{ab}-$ sorbable monofilament, FS (Franklin Silverman) cutting needle; Summerfelt \& Smith 1990), and antibiotic

Table 1. Salmo salar. Fork length (FL), weight (W), and number of detections of Atlantic salmon kelt registered by the receiver array in the coupled estuary-coastal embayment system, York Estuary and Gaspé Bay, and in the Strait of Belle Isle in 2006 and 2007

\begin{tabular}{|c|c|c|c|c|c|c|c|}
\hline \multicolumn{4}{|c|}{2006} & \multicolumn{4}{|c|}{2007} \\
\hline Tag\# & FL (mm) & W (kg) & No. detections & Tag\# & FL (mm) & W (kg) & No. detections \\
\hline 2006-1 & 53 & 1 & 6680 & $2007-1$ & 78 & 3 & 12765 \\
\hline 2006-2 & 81.8 & 3.9 & 4934 & $2007-2$ & 87.3 & 4.6 & 4338 \\
\hline 2006-3 & 95 & 5.9 & 1251 & $2007-3$ & 106 & 9 & 4835 \\
\hline 2006-4 & 82 & 3.3 & 528 & $2007-4$ & 59 & 1.5 & 5520 \\
\hline 2006-5 & 78.5 & 3.1 & 555 & $2007-5$ & 58 & 1.2 & 15763 \\
\hline 2006-6 & 86.5 & 3.5 & 3967 & $2007-6$ & 78.3 & 3.5 & 23184 \\
\hline 2006-7 & 56 & 1 & 819 & $2007-7$ & 101.5 & 8.4 & 3781 \\
\hline $2006-8$ & 78.5 & 3.4 & 861 & $2007-8$ & 84.7 & 4.4 & 3955 \\
\hline $2006-9$ & 80 & 3.5 & 3297 & 2007-9 & 79 & 3.1 & 1686 \\
\hline 2006-10 & 109.5 & 8.5 & 4715 & $2007-10$ & 79.8 & 3.1 & 4606 \\
\hline 2006-11 & 49.5 & 0.8 & 7367 & 2007-11 & 60.5 & 1.6 & 38423 \\
\hline 2006-12 & 60.5 & 1.4 & 7517 & $2007-12$ & 87.5 & 4.4 & 4575 \\
\hline 2006-13 & 58.8 & 1.3 & 2607 & $2007-13$ & 101.5 & 7.6 & 14758 \\
\hline 2006-14 & 79 & 3.4 & 2549 & $2007-14$ & 54.1 & 0.9 & 8221 \\
\hline 2006-15 & 59 & 1.4 & 6638 & $2007-15$ & 98.8 & 7.3 & 17541 \\
\hline 2006-16 & 71.7 & 2.2 & 3885 & $2007-16$ & 81 & 4.1 & 4794 \\
\hline 2006-17 & 56 & 1 & 4910 & $2007-17$ & 82 & 3.7 & 2768 \\
\hline 2006-18 & 58.8 & 1.3 & 4930 & $2007-18$ & 80.5 & 3.2 & 9266 \\
\hline 2006-19 & 51.8 & 0.8 & 783 & 2007-19 & 96 & 7.1 & 4595 \\
\hline $2006-20$ & 78 & 3.5 & 2906 & $2007-20$ & 85.5 & 4 & 9174 \\
\hline $2006-21$ & 84 & 4.1 & 7576 & $2007-21$ & 84.5 & 3.9 & 792 \\
\hline $2006-22$ & 57 & 1.1 & 0 & $2007-22$ & 56 & 0.8 & 1886 \\
\hline $2006-23$ & 59 & 1.2 & 1388 & $2007-23$ & 78 & 3.3 & 0 \\
\hline \multirow[t]{2}{*}{$2006-24$} & 57 & 1.2 & 2794 & $2007-24$ & 94.5 & 6.1 & 4518 \\
\hline & & & & $2007-25$ & 57.5 & 1.3 & 1071 \\
\hline
\end{tabular}


injection (oxytetracycline, $55 \mathrm{mg} \mathrm{kg}^{-1}$ of fish weight; Summerfelt \& Smith 1990).

Migration of the transmitter-tagged kelts was monitored by a fixed receiver array (Vemco Ltd, VR2 model) consisting of: (1) a series of receivers placed longitudinally along the river's delta ( 7 receivers in 2006; 8 receivers in 2007); (2) a continuous array in the estuary, in the inner bay, and on the western margin of the outer bay (62 receivers in 2006; 63 receivers in 2007); (3) a linear array in the outer bay placed from one coast to the other (14 receivers in 2006 and 2007); and (4) a linear array in the Gulf of St. Lawrence, in the Strait of Belle Isle between the Newfoundland and Labrador coasts (22 receivers in 2007) (Fig. 1a). The configuration in the coupled estuary-coastal embayment system for 2006 is shown in Fig. 1C; the configuration for 2007 was almost identical. Receivers in the continuous array were moored on a near-hexagonal grid designed to ensure complete spatial coverage, with a mean distance between neighboring receivers of $570 \mathrm{~m}$. The maximum range of the transmitter within the inner bay was $\sim 650 \mathrm{~m}$, giving considerable overlap in the receiver detection ranges (Hedger et al. 2008a); therefore, the configuration of receivers in the continuous array in the estuary and the inner bay was suitable for the use of non-parametric regression for the interpolation of kelt positions. Receivers outside of the continuous array (in the upper estuary and in the linear arrays in the outer bay, and in the Strait of Belle Isle) were not used for interpolating kelt positions because it was found that they provided only intermittent coverage of only some of the kelts. The Belle Isle linear array, operated by the Atlantic Salmon Federation, was used to monitor migration beyond the coupled estuary-coastal embayment. The mean distance between neighboring receivers located in this linear array was $933 \mathrm{~m}$.

Analysis of the telemetry data. Firstly, the residence time of each kelt in each region (delta, estuary, inner bay and outer bay) was determined. Residence time per region was defined as the time period between first detection in that region to first detection in the subsequent region downstream. Then, within the continuous array (estuary and inner bay), kelt locations were interpolated using kernel smoothing; the rationale being that this could provide a fine-scale interpolation of kelt locations allowing fine-scale patterns and their causes to be identified. A normal kernel (bandwidth = $30 \mathrm{~min}$ ) was used because this has been shown to produce less error than the box kernel (Hedger et al. 2008a). For each kelt, the location was estimated at 10 min intervals (separately in easting and northing dimensions) from the coordinates of the receivers detecting the transmitter signals. Ground speed was then determined as the distance between successive estimated positions over the time difference (10 $\mathrm{min})$.
Characterization of the physical habitat. Continuous measurements of York River discharge were obtained from a flow gauge stationed in the river in 2006 and 2007. Tidal phase was predicted throughout the time that kelts were within the estuary-coastal embayment system using the WTides software package (www.wtides.com), with the prediction verified by measurements within the inner bay. Continuous measurements of water temperature were made during both study years using a thermograph stationed at the mouth of the river delta (depth $=1 \mathrm{~m}$ ) and in the inner bay (depths $=1,9$ and $18 \mathrm{~m}$ ) near to the center of the continuous receiver array.

Vertical profiles of current direction and speed were obtained in 2006 using an Acoustic Doppler Current profiler (ADCP) at depths of 0.0, 2.7, 8.0 and $13.3 \mathrm{~m}$. The thermograph and ADCP data were used to determine temporal variation in water temperature and water velocity in the inner bay as a function of depth. Vertical profiles of salinity were obtained from point measurements made using SEACAT Profiler Conductivity-Temperature-Depth (CTD) dataloggers (SeaBird Electronics Inc.) in July and August 2006. These profiles were obtained too late in the year to be directly used in modeling environmental controls on kelt migration and swimming depth, but they provided contextual information that could be used in the interpretation of any established relationships.

Statistical analysis. Regional differences in kelt residence times were determined using ANOVA. The relationship between kelt residence time in each region and environmental and kelt characteristics was determined using stepwise linear modeling. Predictors were (1) mean discharge from the York River throughout kelt residence in each region, (2) mean water temperature throughout kelt residence in each region, and (3) fork length. Residence times were firstly log transformed to achieve a normal distribution. For the delta and inner bay, temperatures were obtained from the respective thermographs; for the estuary (lying between the delta and the inner bay), the means of the delta and inner bay thermograph temperatures were used. York River discharges were used as a proxy for all discharges into the bay, as discharges from the other river flowing into this bay (River Dartmouth) had a similar intra-annual pattern.

The effects of environmental characteristics and kelt characteristics on kelt seaward ground speed (interpolated at $10 \mathrm{~min}$ intervals) and depth (using data directly obtained from the receivers) were determined using linear mixed-effects modeling. The lme(nlme) function of the open-source package R (Hornik 2009) was used. Seaward kelt ground speed (the $x$-component of kelt ground speed: positive when directed towards the sea in the east and negative when directed 
towards the land in the west) was normally distributed so it could be used as a response variable without a transformation; a log transformation was applied to depth to achieve near-normality. For depth, all observations where the water column depth was $<2 \mathrm{~m}$ were removed because these shallow waters prevented descent to greater depths, which would have biased the analysis of the effect of predictor variables. Predictor variables were chosen as those being the most likely to affect seaward ground speed and depth. Fixed effects were (1) diel period (daytime vs. night), (2) tidal phase (ebb vs. flood), (3) time (the fractional Year Day: e.g. Year Day $=2.5$ is the date at noon on 2 January), and (4) fork length. The individual fish was used as a random effect. A first-order autoregressive model was used to account for the within-group autocorrelation. Fixed effects were then successively removed from each model (from those having least significance to those having most significance) if their removal did not cause a significant reduction in explanatory power.

Relationships between the time taken to migrate across the marine habitat (from Gaspé Bay to the Strait of Belle Isle) and fork length, date of departure from the bay, and residence time within each region of the coupled estuary-coastal embayment were determined by Spearman's rank correlation.

\section{RESULTS}

\section{Physical habitat characteristics}

Surface water temperatures experienced by the kelts increased as they migrated seaward through the estuary-coastal embayment: the mean temperature experienced by the kelts was $4.8^{\circ} \mathrm{C}$ in the delta (delta bay thermograph), $7.6^{\circ} \mathrm{C}$ in the estuary (mean of the delta and inner bay thermograph, depth $=1 \mathrm{~m}$ ) and $9.5^{\circ} \mathrm{C}$ in the inner bay (inner bay thermograph, depth $=1 \mathrm{~m}$ ). The inner bay was mainly thermally stratified. During the time that kelts were being detected in the inner bay, mean temperatures recorded by the inner bay thermograph were $9.5^{\circ} \mathrm{C}($ depth $=1 \mathrm{~m}), 4.3^{\circ} \mathrm{C}($ depth $=$ $9 \mathrm{~m})$ and $1.9^{\circ} \mathrm{C}($ depth $=18 \mathrm{~m})$. Temperatures often varied by several degrees over time periods of several hours, but a significant correlation existed between temperature at a depth of $1 \mathrm{~m}$ and temperature at a depth of $9 \mathrm{~m}$ during the time that kelts were being detected (Spearman's rank correlation, $\rho=0.21$, $\mathrm{n}=$ 4445, $\mathrm{p}<0.001$ in 2006; $\rho=0.48, \mathrm{n}=4445, \mathrm{p}<0.001$ in 2007). Distinct periods of mixing occurred, however, with thermal stratification temporarily disappearing on a non-periodic basis. A trend of increasing temperature with date existed in both years, suggesting the influence of solar forcing. A weak correlation existed between solar elevation and inner bay surface temperature during the time that kelts were being detected $(\rho=-0.03, \mathrm{n}=4380, \mathrm{p}<0.001$ in 2006; $\rho=-0.05, \mathrm{n}=$ 4380, p < 0.001 in 2007), from which it can be inferred that much of the variation in water temperature was caused by changes in mixing rates between waters of terrestrial and marine origins.

Surface water temperatures and currents showed higher short-term heterogeneity than sub-surface temperatures and currents. Diel variation in temperature decreased with increasing depth: mean temperature $\mathrm{SD}=0.78^{\circ} \mathrm{C}($ depth $=1 \mathrm{~m})$; mean temperature $\mathrm{SD}=$ $0.31^{\circ} \mathrm{C}($ depth $=9 \mathrm{~m})$. The correlation between current velocity and seaward tidal gradient increased with depth in the water column: e.g. for the x-component of current speeds from the ADCP and seaward tidal gradient: Spearman's rank correlation, $\rho=0.11, \mathrm{n}=4445$, $\mathrm{p}<0.001$ (depth $=0 \mathrm{~m}) ; \rho=0.42, \mathrm{n}=4445, \mathrm{p}=<0.001$ $($ depth $=2.7 \mathrm{~m}) ; \rho=0.67, \mathrm{p}<0.001($ depth $=8.0 \mathrm{~m}) ; \rho=$ $0.53, \mathrm{n}=4445, \mathrm{p}<0.001$ (depth $=13.3 \mathrm{~m})$.

\section{Kelt migration and swimming depth in coastal zone habitat}

Of the 49 kelts released, 47 were detected by the receiver array (Table 1): one of the undetected kelts (\#2007-23) had eroded fins at capture and exhibited considerable bleeding during surgery, suggesting mortality shortly after release. Of the 47 kelts that were detected, 45 were detected in the inner bay, 41 were detected in the western-most part of the outer bay (to the east of the sand-wedge) and 28 were detected crossing the linear array in the outer bay. Of the 13 kelts detected in the Strait of Belle Isle, 7 were not detected by the linear receiver array in the outer bay. As such, the minimum survival rate between release and the outermost transect located in Gaspé Bay exceeded $70 \%$. Within the estuary, greatest detection rates of kelts occurred within the deeper, eastern region near to the inner bay (Fig. 2); within the inner bay, greatest detection rates occurred on the western margin of the sand-wedge. Kelts migrated out of the delta from 5 to 30 May (median = 8 May) in 2006 and from 9 May to 9 June (median = 25 May) in 2007. Patterns of kelt migration within the inner bay varied markedly according to individual (Figs. $3 \& 4$ ). Twenty-nine kelts (64\% of the sample) showed multiple changes in direction (e.g. \#2006-15, \#2007-7, \#2007-14), 11 kelts (24\% of the sample) showed a highly oriented migration towards the sea (e.g. \#2006-9, \#2007-15, \#2007-19) and 5 kelts (11\% of the sample) were not detected often enough to determine their migration pattern. No difference existed in fork length (Mann-Whitney $U$-test, $W=$ 


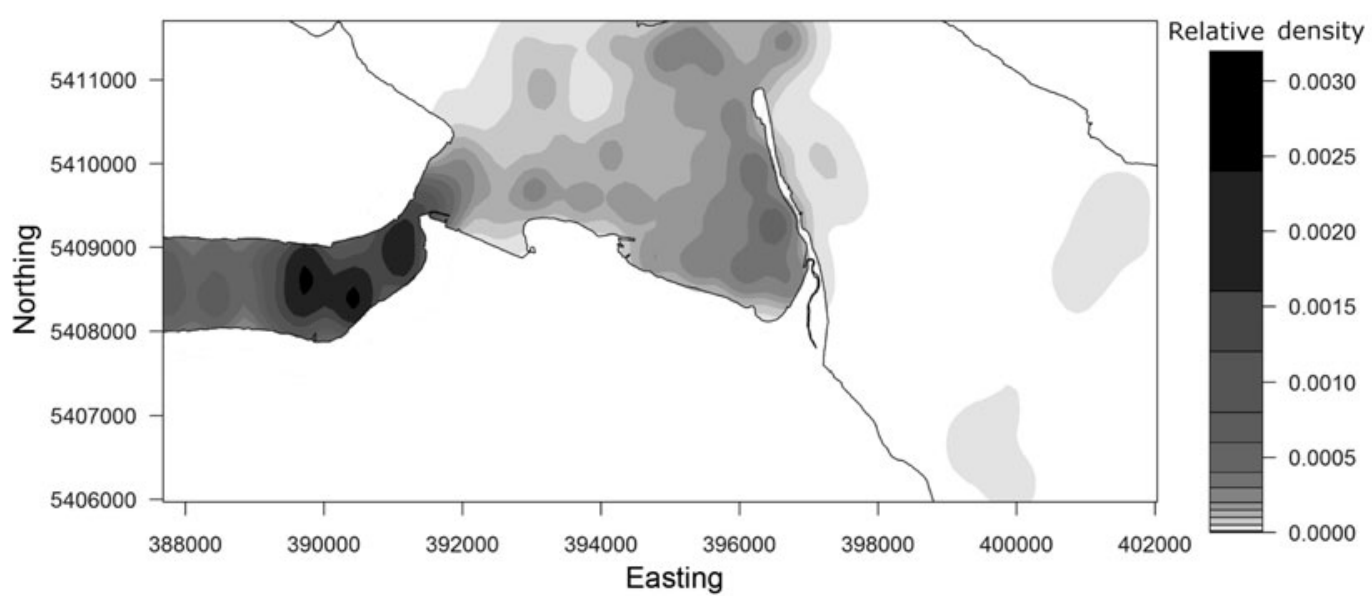

Fig. 2. Salmo salar. Density plot of Atlantic salmon kelt detections in the coupled estuary-coastal embayment system, York Estuary and Gaspé Bay in 2006 and 2007. Coordinates are Universal Transverse Mercator

$165, \mathrm{n}=38, \mathrm{p}=0.879$ ) as to which pattern the kelts followed. Of the kelts that were detected in the most westerly part of the outer bay, 30 migrated through the deep channel separating the inner and outer bays (e.g. \#2006-17) and 11 migrated across the sandwedge (e.g. \#2007-18). Of the 11 kelts that migrated across the sand-wedge, migration occurred when tidal elevation was high (10 migrated during abovemean tidal elevation, and 1 migrated during slightly less than mean tidal elevation). No effect of tidal current direction on migration across the sand-wedge was apparent: 6 migrated during flood tides and 5 migrated during ebb tides.

Kelt swimming depth was mainly near the surface, but kelts exhibited a wide range of depth-use patterns during their migration (Fig. 5). Within the estuary, most kelts remained in near-surface waters $(48.9 \%$ of detections occurred when kelts were within $1 \mathrm{~m}$ of the surface and $99.1 \%$ of detections occurred when kelts were within $5 \mathrm{~m}$ of the surface), but there were some instances of kelts migrating at the bed of the water column throughout the estuary (e.g. \#2007-17) and 21\% of the 47 kelts dived to depths $>2 \mathrm{~m}$ when migrating along the trench separating the estuary from the inner bay (Fig. 5; e.g. \#2006-14, \#2006-18). Within both the inner and outer bay, kelts were again mostly observed within the near-surface layer $(80.7 \%$ of detections occurred when kelts were within $1 \mathrm{~m}$ of the surface and $96.8 \%$ of detections occurred when kelts were within $5 \mathrm{~m}$ of the surface), but diving occurred, either periodically with individual dives lasting several min separated by several hours (e.g. \#2007-14), or in clusters of individual dives extending for periods lasting as long as several hours (e.g. \#2007-10, at the transition between the estuary and bay). The vast majority of dives lasted for short periods of time: $>83 \%$ lasted for

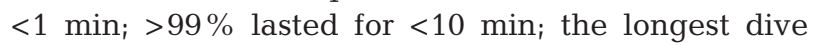

lasted for $\sim 23 \mathrm{~min}$. Not all kelts dived while migrating across the inner bay. Diving was observed in $40 \%$ of 45 kelts detected within the inner bay, although the number of kelts diving may have been greater than this because there were occasional gaps in detections of some kelts. Kelts that dived experienced a large range of temperatures and, to a lesser degree, salinities: temperatures of $\sim 9$ to $9.5^{\circ} \mathrm{C}$ when migrating through the surface layer and of $\sim 4$ to $5^{\circ} \mathrm{C}$ at depths of $\sim 9 \mathrm{~m}$; salinities of $\sim 25 \mathrm{psu}$ in the surface layer $(\leq 1 \mathrm{~m})$ and $\sim 28 \mathrm{psu}$ in the sub-surface layer $(>1 \mathrm{~m}$ ) (from the CTD point samples from 2006).

\section{Factors controlling kelt migration and swimming depth in coastal zone habitat}

Kelt residence time per region decreased significantly as kelts moved through the estuary-coastal embayment system towards the sea (Fig. 6) (ANOVA, $\left.F_{1,176}=123.90, \mathrm{p}<0.001\right):$ delta $(\bar{X}=16.32 \mathrm{~d}, \mathrm{~N}=45)$, estuary $(\bar{X}=1.32 \mathrm{~d}, \mathrm{~N}=44)$, inner bay $(\bar{X}=0.67 \mathrm{~d}, \mathrm{~N}=$ $41)$, outer bay $(\bar{X}=0.23 \mathrm{~d}, \mathrm{~N}=28)$. In the delta, kelt residence time was positively related to mean water temperature and fork length (Table 2). In the estuary and the inner bay, kelt residence time was negatively related to mean discharge and mean water temperature.

The mean absolute ground speed derived from the interpolated kelt positions increased as kelts moved through the system $\left(\right.$ ANOVA, $F_{2,7216}=114.75, \mathrm{p}<$ $0.001)$ : estuary $\left(\bar{X}=20.5 \mathrm{~cm} \mathrm{~s}^{-1}\right)$, inner bay $(\bar{X}=31.6 \mathrm{~cm}$ $\left.\mathrm{s}^{-1}\right)$, outer bay $\left(\bar{X}=46.7 \mathrm{~cm} \mathrm{~s}^{-1}\right)$. Tidal phase was the only significant variable affecting seaward ground speed in the mixed-effects model $(p<0.001)$ with faster seaward ground speed during ebb tide. This model explained $44.8 \%$ of the variation in seaward 

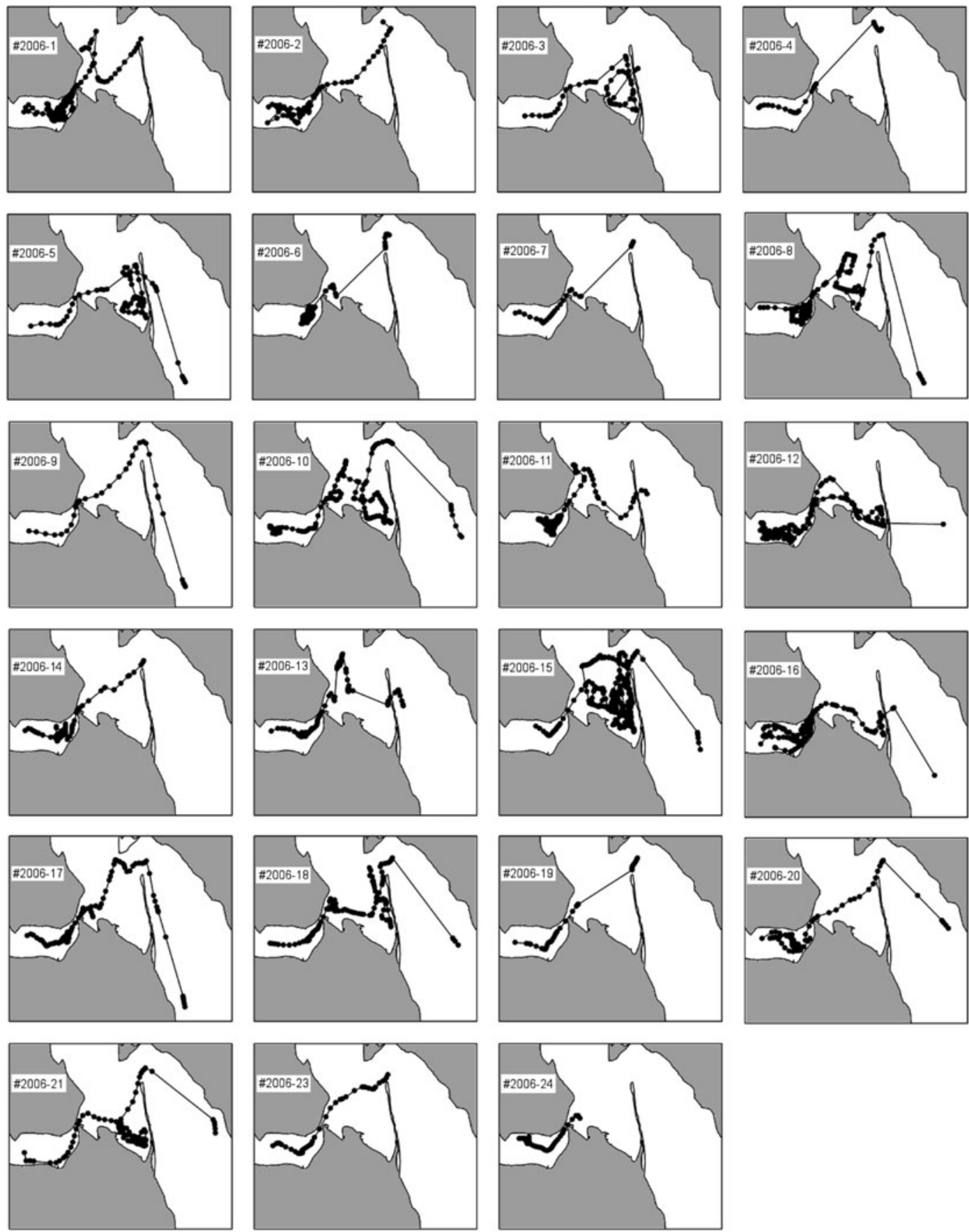

Fig. 3. Salmo salar. Kelt migration patterns in 2006 interpolated using kernel smoothing (time interval = 10 min). Kelts migrate seaward (from the western margin of the York Estuary towards the east). Points indicate interpolated positions. For clarity, points are joined by lines

ground speed within the estuary and inner bay. In both the estuary and the inner bay, mean seaward ground speed was positive on both ebb and flood tides: ebb tide $\left(\bar{X}=14.5 \mathrm{~cm} \mathrm{~s}^{-1}\right)$, flood tide $\left(\bar{X}=3.9 \mathrm{~cm} \mathrm{~s}^{-1}\right)$.

Kelt depths became significantly shallower as kelts traversed the system (ANOVA, $F_{2,63979}=691, \mathrm{p}<$
0.001): estuary $(\bar{X}=1.28 \mathrm{~m})$, inner bay $(\bar{X}=0.82 \mathrm{~m})$, outer bay $(\bar{X}=0.75 \mathrm{~m})$. Diel period was the only significant variable affecting kelt swimming depth $(p<0.001)$ selected by the mixed-effects model, with greater depths occurring during the day. This model explained $89 \%$ of the variance in depth. Mean and maximum 

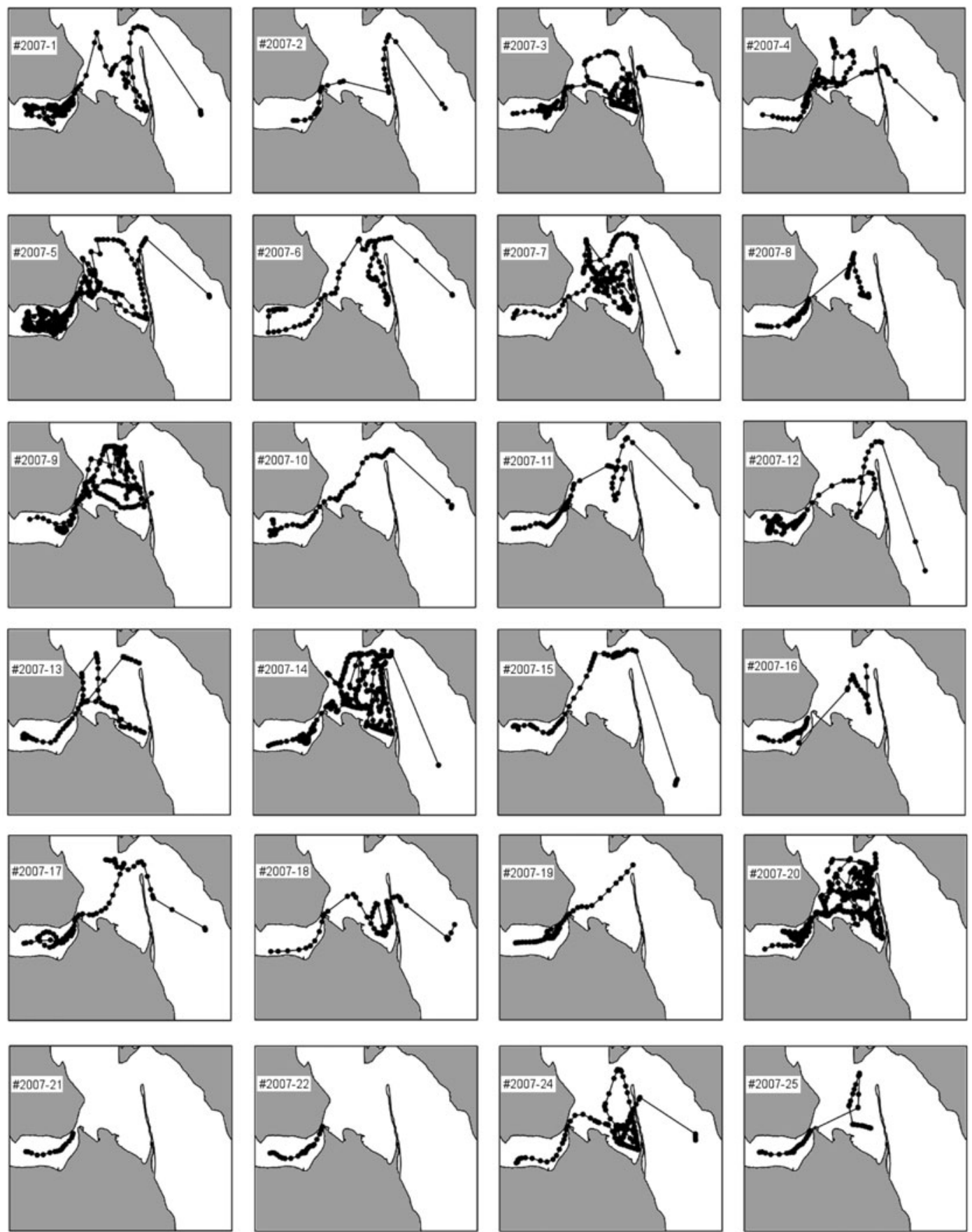

Fig. 4. Salmo salar. Kelt migration patterns in 2007 interpolated using kernel smoothing (time interval = 10 min). Kelts migrate seaward (from the western margin of the York Estuary towards the east). Points indicate interpolated positions. For clarity, points are joined by lines

depth during daytime was greater than that during night in the estuary $\left(\bar{X}_{\text {Day }}=1.81 \mathrm{~m}, \bar{X}_{\text {Night }}=0.75 \mathrm{~m}\right.$; $\max _{\text {Day }}=16.9 \mathrm{~m}$, max $\left._{\text {Night }}=10.7 \mathrm{~m}\right)$, in the inner bay $\left(\bar{X}_{\text {Day }}=0.99 \mathrm{~m}, \bar{X}_{\text {Day }}=0.79 \mathrm{~m} ; \max _{\text {Day }}=41.0 \mathrm{~m}\right.$, max. Night $=9.0 \mathrm{~m})$ and in the outer bay $\left(\bar{X}_{\text {Night }}=0.97 \mathrm{~m}\right.$, $\left.\bar{X}_{\text {Day }}=0.63 \mathrm{~m} ; \max _{\text {Night }}=15.0 \mathrm{~m}, \max \cdot{ }_{\text {Night }}=7.0 \mathrm{~m}\right)$.

\section{Kelt migration and swimming depth in} marine habitat

In 2006, none of the tagged kelts were detected in the Strait of Belle Isle, but the receivers were deployed late in the season on 10 July so kelts may have passed 

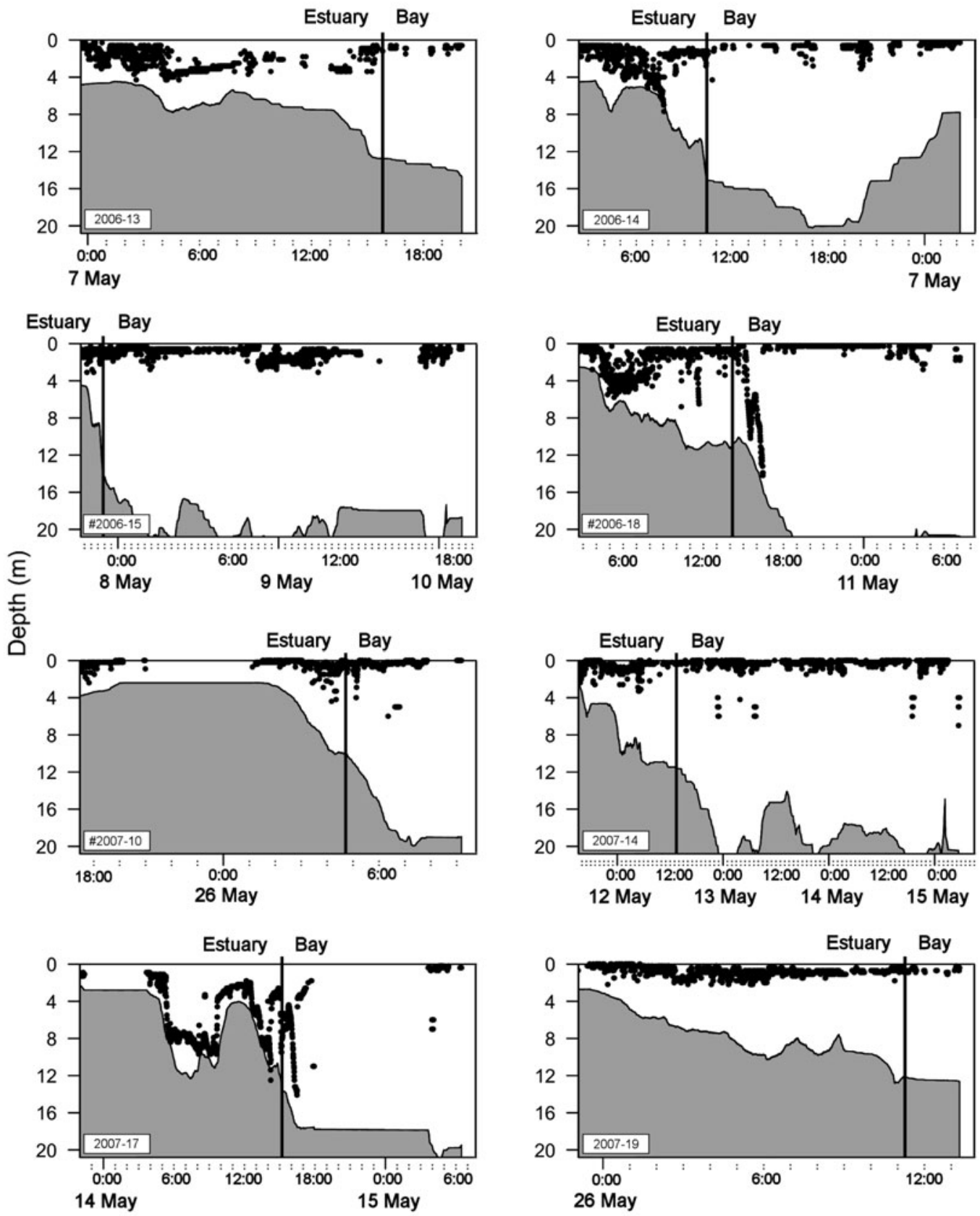

Fig. 5. Salmo salar. Depth plots of 8 Atlantic salmon kelts in the York River estuary and the Gaspé bay. The bed of the estuary and bay is shown by the filled gray area

through the strait before the deployment. Thirteen kelts were detected in the Strait of Belle Isle in 2007. In that year, kelts had left Gaspé Bay from 11 May to 10 June and were detected in the Strait of Belle Isle from 1 to 15 July. Kelts covered a distance of 639 to $650 \mathrm{~km}$ in the open sea in a mean time period of $45 \mathrm{~d}$ (range: 27 to $62 \mathrm{~d}$ ) at a mean ground speed of $15 \mathrm{~km} \mathrm{~d}^{-1}$ (range: 10 to $24 \mathrm{~km} \mathrm{~d}^{-1}$ ). No relationship existed between marine ground speed and length (Spearman rank correlation, $\rho=0.26, \mathrm{n}=13, \mathrm{p}=0.378$ ) or time taken to migrate across the inner and outer bays $(\rho=0.18, \mathrm{n}=13, \mathrm{p}=$ 0.595). However, a strong positive relationship existed between marine ground speed and date of departure from Gaspé Bay ( $\rho=0.877, \mathrm{n}=13, \mathrm{p}<0.001)$. The mean ground speed was $11 \mathrm{~km} \mathrm{~d}^{-1}$ (range: 10 to $12, \mathrm{n}=3$ ) for kelts leaving in early May, $15 \mathrm{~km} \mathrm{~d}^{-1}$ (range: 13 to 18 , $\mathrm{n}=7$ ) for kelts leaving at the end of May, and $22 \mathrm{~km} \mathrm{~d}^{-1}$ (range: 18 to $24, \mathrm{n}=3$ ) for kelts leaving in early June. A strong positive relationship also existed between marine ground speed and kelt residence time in the 
delta $(\rho=0.807, n=13, p<0.001)$. No significant relationship was found for any other region of the coupled estuary-coastal embayment.

Kelt swimming depth in the Strait of Belle Isle occurred mainly in the near-surface water $78 \%$ of the 144 detections indicated a kelt depth of $\leq 1 \mathrm{~m}$ from the surface). The mean swimming depth of sonic-tagged kelts ranged from 0.22 to $3.80 \mathrm{~m}$. Diving behavior was observed for short time periods ( $<1$ to $6 \mathrm{~min}$ ) for only 3 of the 13 kelts. Swimming depth during diving ranged from 4 to $15 \mathrm{~m}$.

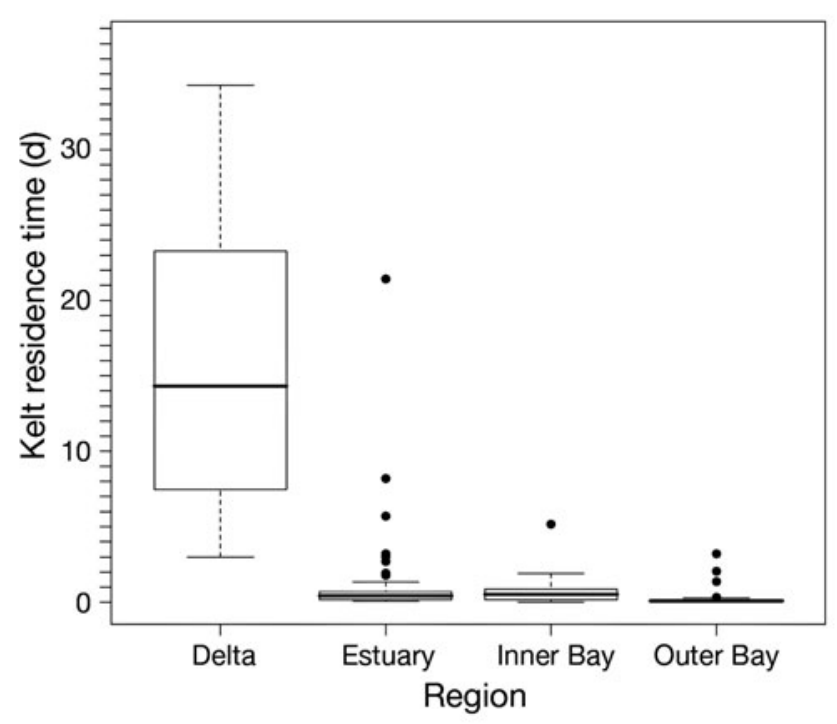

Fig. 6. Salmo salar. Atlantic salmon kelt residence time according to region. Thick horizontal line = median; the box bounds the first and third quartiles; whiskers = all values out side box within $1.5 \times$ interquartile range

Table 2. Salmo salar. Effect of discharge, mean temperature and fork length on kelt residence time within the delta, estuary and inner bay as determined using stepwise linear modeling

\begin{tabular}{|lrrrr|}
\hline & Estimate & $\mathrm{SE}$ & $t$-value & $\mathrm{p}$-value \\
\hline Delta & & & & \\
(Intercept) & -1.520 & 0.650 & -2.338 & 0.024 \\
Mean water temperature & 0.574 & 0.121 & 4.723 & $<0.001$ \\
Fork length & 0.015 & 0.004 & 3.631 & $<0.001$ \\
Adjusted $\mathrm{R}^{2}=0.53, F_{3,37}=23.06, \mathrm{p}<0.001$ & & & \\
Estuary & & & & \\
(Intercept) & 4.532 & 1.398 & 3.241 & 0.002 \\
Mean discharge & -0.034 & 0.009 & -3.567 & $<0.001$ \\
Mean water temperature & -0.405 & 0.110 & $3-3.671<0.001$ \\
Adjusted $\mathrm{R}^{2}=0.24 F_{2,39}=7.43, \mathrm{p}<0.001$ & & & \\
Inner Bay & & & & \\
(Intercept) & 2.584 & 0.855 & 3.019 & 0.005 \\
Mean discharge & -0.013 & 0.007 & -1.807 & $<0.081$ \\
Mean water temperature & -0.271 & 0.072 & -3.771 & $<0.001$ \\
Adjusted $\mathrm{R}^{2}=0.31, F_{2,27}=7.66, \mathrm{p}=0.002$ & & & \\
\hline
\end{tabular}

\section{DISCUSSION}

\section{Factors controlling coastal zone migration}

Kelts resided in the delta for relatively long periods (up to several weeks), followed in most cases by rapid seaward migration on reaching the estuary. The lack of a relationship with discharge in the delta indicates that kelts were actively maintaining station within the delta. We hypothesize that long-term residence in the delta resulted from a period of feeding in response to the requirement to improve somatic reserves for seaward migration. Atlantic salmon lose between 60 and $70 \%$ of their body reserves due to upstream migration and spawning (Jonsson et al. 1997). Rapid seaward migration of fish surviving to the spring following spawning thus requires the restoration of some minimum level of somatic reserves. This hypothesis is supported by the fact that residence time in the delta was positively related to fork length. Both absolute and relative energy losses in Atlantic salmon during migration and spawning increase with fish length (Jonsson et al. 1997), probably due to the relatively higher maintenance metabolism in larger fish (Jonsson et al. 1991). Larger post-spawning fish would then be expected to require more time to build their energy reserves prior to seaward migration. Although there is no information on food availability across the delta-estuary-embayment, the delta is characterized by shallow waters and extensive macrophyte beds: ideal settings for the development of an invertebrate fauna and the forage fish that prey upon them. The longer kelt residence within the delta with increasing temperatures $\left(\sim 4.5^{\circ} \mathrm{C}\right.$ to $6.5^{\circ} \mathrm{C}$ ) may reflect the increasing profitability of the delta for feeding and the accumulation of energy stores.

The pattern of rapid seaward migration of Atlantic salmon kelts after a period of extended river residence is similar to that identified by Halttunen et al. (2009) in Alta Fjord (Norway), where kelts initiated their migration an average of $18 \mathrm{~d}$ after tagging, but differs somewhat to the pattern identified by Hubley et al. (2008) in the LaHave River and Estuary (Nova Scotia, Canada) where no initial longterm residence in the river was found. Kelt migration speeds across the estuary-embayment in our study $(\sim 12 \mathrm{~km}$ $\mathrm{d}^{-1}$ ) were less than those of kelts in the fjord studied by Halttunnen et al. (2009) $\left(\sim 40 \mathrm{~km} \mathrm{~d}^{-1}\right)$ but were greater than those of kelts in the estuary studied by Hubley et al. (2008) $\left(\sim 2 \mathrm{~km} \mathrm{~d}^{-1}\right)$. 
The faster migration within the Alta Fjord may have been related to its greater salinities that have generally been associated with rapid seaward migration of salmon. The increase in seaward migration speed with an increase in proximity to the sea that was found in our study concurred with that found in the studies of Halttunen et al. (2009) and that of Hubley et al. (2008). This increase occurred across all monitored parts of the fjord in Halttunen's study, but was only consistently found in the outer-most part of the coastal area in Hubley's study. The shorter residence times observed in the estuary and embayment in the present study when temperatures were warm and discharges were high is suggestive of an orthokinetic increase in seaward swimming speed in response to an increase in temperature (see Bendall et al. 2005) and the use of the seaward residual current to aid seaward migration.

The mixed-effects model showed that kelt seaward movement was controlled by tidal phase (faster seaward migration on the ebb tide). Tidal phase has consistently been identified throughout the literature as being a control of migration of Atlantic salmon within the coastal zone, and seaward migration on the ebb tide has been proposed as being the most energetically efficient form of seaward migration (Bendall et al. 2005). No diel control was apparent. The pattern of diel control on kelt seaward migration had been less consistent throughout the literature (Bendall et al. 2005 and Scruton et al. 2007 identifying nocturnal migration; Östergren \& Rivinoja 2008 identifying daytime migration). We hypothesize that the lack of a tendency for nocturnal migration is suggestive of low predation pressure on the kelts from piscivorous fish and birds: avoidance of predation should cause a preference for movement under the cover of darkness (Bendall et al. 2005). Swimming depth however was greatest during daytime. Diving during daytime could be associated with either feeding behavior or the identification of bed features to aid in orientation out of the estuarycoastal embayment system, light being required for either of these processes.

\section{Seaward orientation and swimming depth}

Several behavioral mechanisms may have been exploited by kelts to achieve active seaward migration out of the estuary and bay. The most probable mechanism would involve a response to properties of the body of water. Temperature and salinity gradients and current directions may have played a role in kelt orientation, as has been identified for smolts in both the estuary (Martin et al. 2009) and the inner bay (Hedger et al. 2008b). Within the inner bay, more kelts migrated towards the deep channel separating this bay from the outer bay than towards the sand-wedge. Stronger salinity gradients across the inner bay and more temporally consistent current directions were identified towards the deep channel than towards the sandwedge, so this may have been a mechanism by which kelts oriented themselves. Additionally, we speculate that swimming at depth may have been associated with the requirement for detecting temporally consistent terrestrial-marine gradients in temperature and salinity and/or temporally consistent current flow directions for establishing orientation. Surface eddying in the inner bay has been seen to temporarily destroy temperature and salinity gradients (or reverse them) on a non-periodic basis, and superimpose a seemingly chaotic current flow direction and speed on the more predictable tidal-induced flow (Hedger et al. 2008b). The data from the inner bay thermograph and ADCP showed that short-term heterogeneity in temperature and currents decreased with increasing depth (and by inference, salinity will have become less variable), so kelts may have been diving to experience these more temporally consistent temperature and salinity gradients and current flows. These observations of kelt migration are also consistent with the hypothesis that kelts exploit an innate compass to maintain a preferred bearing (reviewed in Dodson 1988), as suggested for smolts in this area by Hedger et al. (2008b) and Martin et al. (2009). Finally, the preferred eastward bearing may have been a conditioned response (Dodson 1988, Smith \& Smith 1998). Throughout the time when kelts were within the York River, they were swimming in an eastward direction against a gradient of increasing salinity. It is possible that they associated an increase in salinity with swimming in an eastward direction and that this eastward bias continued on their transition into the inner bay.

\section{Behavioral consistency across life-stages of Atlantic salmon within the coastal zone}

Two characteristics of kelt migration patterns have also been observed in salmon smolts within York Estuary and Gaspé Bay (Hedger et al. 2008b; Martin et al. 2009): (1) increased seaward ground speed as the individual passed from the estuary into the bay, and (2) increased rates of seaward migration on the ebb tide. Some differences also existed. Firstly, Martin et al. (2009) showed that most smolt movements in the estuary were in an upstream direction during the flood tide (i.e. positive rheotaxis regardless of current direction), whereas our study of kelts showed that, although the seaward ground speed decreased during the flood tide, the net movement on the flood tide was still in a seaward direction. Secondly, kelt migration across the 
system was faster (with the exception of the delta) and a greater proportion exited the system than in the smolt study of Hedger et al. (2008b): kelts were more strongly and actively migrating offshore. Finally, diel effects on kelt seaward migration speed appeared to be minimal. The overall pattern of behavior, however, appeared to be retained from the smolt to the kelt lifestage, although kelt seaward migration appeared to be more pronounced.

\section{Marine migration}

The fact that high detection rates occurred in the Strait of Belle Isle is unique evidence that salmon spawning in rivers in the south-western part of the Gulf of St. Lawrence migrate to offshore areas through the Strait of Belle Isle. Assuming that the $~ 50 \%$ detection rate observed in 2007 in the Strait of Belle Isle is a minimum estimate of the proportion of potential repeat spawners that opt for alternative-year spawning rather than consecutive year spawning, it may be hypothesized that the increase in reproductive success afforded by increased growth at sea requires that kelts leave the Gulf of St. Lawrence, possibly because of cold winter temperatures along the coast. Further analysis of the life-histories and physiological characteristics of kelts migrating from rivers within the Gulf of St. Lawrence is warranted to further explore the proximate control and fitness benefits of these 2 alternative repeat spawning strategies.

The speed of migration between Gaspé Bay and the Strait of Belle Isle was positively related to the date of departure from Gaspé Bay. Two non-exclusive hypotheses can be proposed. On one hand, the relationship with date of departure may have been an artifact of a relationship between date of departure and the physical condition of kelts. The main influence on the date of departure from Gaspé Bay was the length of time that the kelts remained within the delta. That is, those kelts which resided within the delta for a long period of time showed rapid migration during the marine phase. It is therefore possible that the kelts which were rapidly migrating had remained within the delta long enough for them to have achieved sufficient physical condition to enable rapid migration. On the other hand, the speed of migration may have been related to a temporally dependent characteristic of the marine habitat (for example, an increase in sea surface temperature). Warmer temperatures are associated with higher metabolic rates and faster sustained swimming speeds. In either case, the non-significant relationship between marine migration rate and fish length was unexpected and may be explained by the small sample size of fish that were detected in the Strait of Belle Isle.

\section{CONCLUSIONS}

Three main controls on coastal zone migratory behavior were apparent: (1) a geographical control, with kelts showing extended residence in the river delta section of the upper estuary, followed by rapid seaward migration through the estuary and coastal embayment; (2) a diel control, with diving behavior during daytime (hypothesized to be a mechanism to exploit more stable physical gradients); and (3) a tidal control, with faster seaward migration on the ebb tide. There was strong evidence of active migration, with resistance to displacement in the river delta and rapid seaward migration on reaching the estuary and bay. The patterns of migration within the coastal zone were broadly similar to those previously identified for smolts in the same location, suggesting that there are universal patterns of migratory behavior in both life-history stages within the coastal zone. Kelts within the marine environment were detected in the Strait of Belle Isle: the only time that kelt migration from a river in Gaspésie to this area has been detected. Speed of migration within the marine environment was dependent on date of departure from Gaspé Bay, which in turn was dependent on residence time within the delta. It was hypothesized that extended residence within the delta enabled kelts to improve their physical condition to ensure rapid migration within the marine environment.

Acknowledgements. The study was funded by contributions from GEOIDE (GEOmatics for Informed DEcisions, a Canadian Centre of Excellence), the Ministère des Ressources Naturelles et de la Faune du Québec, the Atlantic Salmon Federation, the Centre collégial de transfert de technologie des pêches (CCTTP-CSP, Grande Rivière), the Fondation pour le saumon du Grand Gaspé, ALCAN Inc., and QuébecOcéan. We thank P. Brooking and G. Doucette of the Atlantic Salmon Federation, J. Roy of the Société de gestion des rivières du Grand Gaspé, and V. Cauchon, N. Harnois, Y. Soulard, A. Leblanc, S. Leblanc, M. Lalonde, S. Landry, M. Grenier, É. Valiquette, A. Richard, and J.-F. Bourque for their assistance in field-work. This is a contribution to the programme of CIRSA (Centre Interuniversitaire de Recherche sur le Saumon Atlantique) and Québec-Océan.

\section{LITERATURE CITED}

Allan IRH, Ritter JA (1977) Salmonid terminology. ICES J Mar Sci 37:293-299

Bardonnet A, Baglinière JL (2000) Freshwater habitat of Atlantic salmon (Salmo salar). Can J Fish Aquat Sci 57: 497-506

Belding DL (1940) Migration of the Atlantic Salmon (Salmo salar) in the Gulf of St. Lawrence as determined by tagging experiments. Trans Am Fish Soc 69:290-295

> Bendall B, Moore A, Quayle V (2005) The post-spawning movements of migratory brown trout Salmo trutta L. J Fish 
Biol 67:809-822

Caron F (1983) Migration vers l'Atlantique des postsaumoneaux (Salmo salar) du golfe du Saint-Laurent. Naturaliste can (Rev Ecol Syst) 110: 223-227

Carrière JB (1973) A physical oceanographic study of the Havre and Baie de Gaspé. MSc thesis, Dalhouse University, Halifax

Colombani F, Maltais A, Dodson JJ (1998) La pêche commerciale du saumon atlantique (Salmo salar) sur la Basse Côte-Nord du Saint-Laurent: une analyse génétique de la relation des prises commerciales avec cinq populations de la Côte-Nord. Rapport final présenté au ministère de l'Environnement et de la Faune du Québec. Sept-Île et Québec, p 1-74, available at www.bio.ulaval.ca/cirsa/ Publications/Colombani\%20MEF.pdf

Dodson JJ (1988) The nature and role of learning in the orientation and migratory behavior of fishes. Environ Biol Fishes 23:161-182

Doving KB, Westerberg J, Johnsen PB (1985) Role of olfaction in the behavioural and neuronal responses of Atlantic salmon, Salmo salar, to hydrographic stratification. Can J Fish Aquat Sci 42:1658-1667

Ducharme LJA (1969) Atlantic salmon returning for their fifth and sixth consecutive spawning trips. J Fish Res Board Can 26:1661-1664

Finstad B, Økland F, Thorstad EB, Bjorn PA, McKinley RS (2005) Migration of hatchery-reared Atlantic salmon and wild anadromous brown trout post-smolts in a Norwegian fjord system. J Fish Biol 66:86-96

Halttunen E, Rikardsen AH, Davidsen JG, Thorstad EB, Dempson JB (2009) Survival, migration speed and swimming depth of Atlantic salmon kelts during sea entry and fjord migration. In: Nielsen JL, Arrizabalaga H, Fragoso N, Hobday A, Lutcavage M, Sibert J (eds) Tagging and tracking of marine animals with electronic devices II. Reviews: Methods and Technologies in Fish Biology and Fisheries, 9. Springer, Dordrecht, p 35-50

Hedger RD, Martin F, Dodson JJ, Hatin D, Caron F, Whoriskey FG (2008a) Optimized interpolation of fish positions and speeds in an array of fixed acoustic receivers. ICES J Mar Sci 65:1248-1259

Hedger RD, Martin F, Hatin D, Caron F, Whoriskey GF, Dodson JJ (2008b) Active migration of wild Atlantic salmon Salmo salar L. smolt through a coastal embayment. Mar Ecol Prog Ser 355:235-246

Holden C (2006) Sound sightings. Science 313:777

Hornik K (2009) The R FAQ. ISBN 3-900051-08-9. http:// CRAN.R-project.org/doc/FAQ/R-FAQ.html

Hubley PB, Amiro PG, Gibson AJF, Lacroix GL, Redden AM (2008) Survival and behaviour of migrating Atlantic salmon (Salmo salar L.) kelts in river, estuarine, and coastal habitat. ICES J Mar Sci 65:1626-1634

- Jonsson N, Hansen LP, Jonsson B (1991) Variation in age, size and repeat spawning of adult Atlantic salmon in relation to river discharge. J Anim Ecol 60:937-947

Jonsson N, Jonsson B, Hansen LP (1997) Changes in proximate compositions and estimates of energetic costs during upstream migration and spawning in Atlantic salmon Salmo salar. J Anim Ecol 66:425-436

Karlsson L, Ikonen E, Westerberg H, Sturlaugsson J (1996) Use of data storage tags to study the spawning migration of Baltic salmon (Salmo salar L.) in the Gulf of Bothnia. ICES CM 1996/M:9

Koutitonsky VG, Desrosiers G, Pelletier E, Zakardjian B and others (2001) Études hydrodynamique, sédimentologique et benthique pour le choix de sites de mariculture d'omble de fontaine dans la baie de Gaspé. Rapport LHE 01-1, Institut des sciences de la mer de Rimouski, QUAR, Rimouski

Lacroix GL, Knox D, Stokesbury MJW (2005) Survival and behaviour of post-smolt Atlantic salmon in coastal habitat with extreme tides. J Fish Biol 66:485-498

Martin F, Hedger RD, Dodson JJ, Fernandes L, Caron F, Hatin D, Whoriskey FG (2009) Behavioural transition during the estuarine migration of wild Atlantic salmon (Salmo salar L.) smolt. Ecol Freshw Fish 18:406-417

> Niemelä E, Makinen TS, Moen K, Hassinen E, Erkinaro J, Lansman M, Julkunen M (2000) Age, sex ratio and timing of the catch of kelts and ascending Atlantic salmon in the subarctic River Teno. J Fish Biol 56:974-985

$>$ Økland F, Thorstad EB, Finstad B, Sivertsgard R, Plantalech N, Jepsen N, McKinley RS (2006) Swimming speeds and orientation of wild Atlantic salmon post-smolts during the first stage of the marine migration. Fish Manag Ecol 13: $271-274$

Östergren J, Rivinoja P (2008) Overwintering and downstream migration of sea trout (Salmo trutta L.) kelts under regulated flows - northern Sweden River Research and Applications, Regulated Rivers. Res Manag 24:551-563

Reddin DG, Friedland KD, Downton P, Dempson JB, Mullins CC (2004) Thermal habitat experienced by Atlantic salmon (Salmo salar L.) kelts in coastal Newfoundland waters. Fish Oceanogr 13:24-35

Ritter JA (1989) Marine migration and natural mortality of North American Atlantic salmon (Salmo salar L.). Can MS Rep Fish Aquat Sci 2041

Scruton DA, Pennell CJ, Bourgeois CE, Goosney RF, Porter TR, Clarke KD (2007) Assessment of a retrofitted downstream fish bypass system for wild Atlantic salmon (Salmo salar) smolts and kelts at a hydroelectric facility on the Exploits River, Newfoundland, Canada. Hydrobiologia 582:155-169

Smith RJF, Smith MJ (1998) Rapid acquisition of directional preferences by migratory juveniles of two amphidromous Hawaiian gobies, Awaous guamensis and Sicyopterus stimpsoni. Environ Biol Fishes 53:275-282

Summerfelt RC, Smith LS (1990) Anesthesia, surgery, and related techniques. In: Schreck CB, Moyle PB (eds) Methods for fish biology. American Fisheries Society, Bethesda, MD, p 213-272

- Thorstad EB, Økland F, Finstad B, Sivertsgard R, Bjorn PA, McKinley RS (2004) Migration speeds and orientation of Atlantic salmon and sea trout post-smolts in a Norwegian fjord system. Environ Biol Fishes 71:305-311

Voegeli FA, Lacroix GL, Anderson JM (1998) Development of miniature pingers for tracking Atlantic salmon smolts at sea. Hydrobiologia 371-372:35-46

Wada K, Ueno Y (1999) Homing behaviour of chum salmon determined by an archival tag. NPAFC (North Pacific Anadroumous Fish Commission) Doc 425, National Salmon Resources Center, Sapporo

Walker RV, Myers KW, Davis ND, Aydin KY and others (2001) Diurnal variation in thermal environment experienced by salmonids in the North Pacific as indicated by data storage tags. Fish Oceanogr 9:171-186

Westerberg H (1984) The orientation of fish and vertical stratification at fine- and micro-structure scales. In: McCleave JD, Arnold GP, Dodson JJ, Neil WH (eds) Mechanisms of migration in fishes. NATO Conference Series, Series IV: Marine Sciences, Plenum Press, New York, p 179-203 